\title{
The power to convene: making sense of the power of food movement organizations in governance processes in the Global North
}

\author{
Jill K. Clark ${ }^{1}$ D Kristen Lowitt $^{2}$ (D) Charles Z. Levkoe $^{3}$ D $\cdot$ Peter Andrée $^{4}(\mathbb{D}$
}

Accepted: 21 August 2020 / Published online: 31 August 2020

(c) Springer Nature B.V. 2020

\begin{abstract}
Dominant food systems, based on industrial methods and corporate control, are in a state of flux. To enable the transition towards more sustainable and just food systems, food movements are claiming new roles in governance. These movements, and the initiatives they spearhead, are associated with a range of labels (e.g., food sovereignty, food justice, and community food security) and use a variety of strategies to enact change. In this paper, we use the concept of relational fields to conduct a post-hoc analysis of nine cases, examining how social movement organizations and other actors actively create new deliberative governance spaces. We argue that successes are related to the "power to convene," a process-oriented approach that increases movements' capacity to mobilize; leverage different types of power; and integrate, coordinate, and build a systems-oriented vision. The power to convene and create deliberative spaces is demonstrated in a variety of contexts and often results in outcomes that further movement aims, including policy change and repositioning food movement actors visà-vis others in the field. Our findings suggest that success is not only measured as policy outcomes, but as an advantageous repositioning of social movement actors that enables them to be part of governance processes beyond simple policy advocacy.
\end{abstract}

Keywords Food movements $\cdot$ Governance $\cdot$ Sustainable food systems $\cdot$ Interactive governance $\cdot$ Relational fields $\cdot$ Deliberation

\begin{tabular}{ll}
\multicolumn{2}{l}{ Abbreviations } \\
AOC & Appellation d'Origine Controlée \\
BFN & Batchewana First Nation \\
CSM & Civil Society and Indigenous Peoples' Mechanism \\
CFS & Committee on World Food Security \\
FSC & Food Secure Canada \\
NWT & Northwest Territories \\
OFN & Our Food Network Dunedin \\
SON & Saugeen Ojibway Nation \\
F2P & Vermont Farm to Plate Network \\
YYC & YYC Growers and Distributors
\end{tabular}

Jill K. Clark

clark.1099@osu.edu

1 John Glenn College of Public Affairs, Ohio State University, 1810 College Road, Columbus, OH 43210, USA

2 School of Environmental Studies, Queen's University, BioSciences Complex, Room 3134, Kingston, ON K7L 3N6, Canada

3 Department of Health Sciences, Lakehead University, 955 Oliver Rd, Thunder Bay, ON P7B 5E1, Canada

4 Department of Political Science, Carleton University, 1125 Colonel By Drive, Ottawa, ON K1S 5B6, Canada

\section{Introduction}

Food systems are in a state of flux as the result of a wide range of intersecting forces, including consumer and producer/harvester demands, technological changes, financialization, and climate change (Clapp 2016; Andrée et al. 2014). This has led to the instability of the dominant food system, which is premised on industrial methods and corporate control. A major limitation of food systems' resilience is that food-related policies tend to favor economic development over people's access to healthy and culturally appropriate food that is produced and harvested in socially just and ecologically sustainable ways. The net result is a food system that is over-reliant on fossil fuels and chemical inputs in farming and fishing (Pauly et al. 2000; Weis 2013; Altieri 2018), with low wages and poor labor conditions among food workers (Gray 2013; Jayaraman 2013), low returns for family farms and small-scale fishers (Renting et al. 2003), ongoing land appropriation (Williams and Holt-Giménez 2017), and limited access to healthy foods for many people (Power 2008; Dachner and Tarasuk 2016). Corporations and businesses have had disproportionate influence over decision-making, and food systems policy has remained siloed 
and ineffective at addressing most of these issues (Lang et al. 2009). Food system problems like these represent both challenges and opportunities for social movements organizing to build a more sustainable and just world (Levkoe 2014; Wittman et al. 2010).

To enable the transition towards more sustainable and just food systems, food movements, through the organizations coalescing within them, are claiming new roles in governance. By food movements we mean the networks of people, groups, and organizations that are challenging industrial food systems by experimenting with a variety of alternative ways of producing, harvesting, foraging, processing, distributing, consuming, and, ultimately, governing food. These movements, and the initiatives they spearhead, are associated with a range of labels, including fair trade, civic agriculture, food justice, food sovereignty, agroecology, slow food, and community food security (Hendrickson and Heffernon 2002; Friedland 2010; Schiff and Levkoe 2014). We refer to food movements in the plural to recognize their diversity as well as their interconnections (Constance et al. 2014; Levkoe 2015). Although food movements can be diverse in their tactics and activities, they tend to share in a critique of the dominant industrial model and, collectively, aim to reinforce, build on, and scale-up innovative, place-based initiatives to supplant or displace the dominant industrial systems. This involves not only engaging with government through public participation strategies, but also increasingly engaging in food system governance to further food movement goals. Governance refers to the relationships, processes, rules, practices, and structures (both institutional and discursive) through which power and control are exercised and decisions are made. Growing involvement by food movement actors in governance has been observed across the Global North, with groups building on place-based experiences to work with others and alter government and corporate policies (Andrée et al. 2019).

A growing literature examines social movement engagement with governance processes. For example, Holt Giménez and Shattuck (2011) compare a range of positions held by food movements, delineating them according to their politics, orientation, and discourse. These authors argue that a radical structural analysis (such as those found in food sovereignty movements) is useful for progressives seeking to scale-up projects in order to achieve greater power and, ultimately, structural change. Grounded in a similar perspective, Desmarais et al. (2017) consider the risks and opportunities involved in translating food sovereignty goals into state laws, policies, and programs through a diverse set of case studies. Meanwhile, Laforge et al. (2017) suggest that food movement actors need to think more critically about their engagement with the state because of the tensions resulting from such collaboration (see also Levkoe and Wilson 2019). Polycentric governance theory brings a distinct perspective to these issues. Polycentricity understands the political arena in terms of the coexistence of multiple centers of power and control and, therefore, multiple governance arrangements (Nagendra and Ostrom 2012; Aligica and Tarko 2012). Further, polycentricity pushes the conceptualization of governance beyond simple dichotomies of the "market" and the "state" (Ostrom 2010).

Informed by this literature, this paper focuses on civil society, ${ }^{1}$ with specific attention paid to food movement organizations, groups that attempt to wield power within specific governance arrangements (or relationships between elements of governance) or create new arrangements as they stake claims to decision-making. While it is well-established that corporate interests have a disproportionate influence on decision-making in the global food system (Clapp 2016), our analysis focuses centrally on social movement organizations as new entrants into governance arrangements. Relationally, this suggests that the use of power is paramount. Structurally, interactive governance theory suggests that power relationships find expression in at least three key modes of governance that characterize governance arrangements: hierarchical governance (which we term multi-stakeholderism), co-governance, and self-governance (Kooiman 2003).

An emphasis on interactivity aligns with emerging conceptual approaches to the study of social movements and networks (Crossley and Diani 2018), including attention paid by scholars to the factors that enable movement effectiveness, such as network embeddedness and desire and willingness to engage in collaborative governance (Ansell 2003; Martin 2003). Goldstone (2004) describes the idea of "relational fields," arguing that social movements should not be viewed simply in terms of fighting states, but as part of changing, issue-specific relational fields comprised of the actions and interests of the state, allied and countermovement groups, and the broader citizenry, all interacting to shape the emergence, activities, and outcomes of social movements (p. 333). Conceptualizing interactions as fields sheds light on the emergent conditions of social movements and blurs the lines between outside organizing and everyday politics in democratic societies (Alimi et al. 2015; Goldstone 2004; Moss and Snow 2016).

Witnessing the dynamic interactivity of food movement organizations with the state inspired a collective project to examine this phenomenon. The Food: Locally Embedded Globally Engaged (FLEdGE) network is a communityengaged research partnership exploring the current and potential role of community food initiatives to act as pillars of regional, sustainable food systems. In September 2017,

\footnotetext{
${ }^{1}$ Civil society refers to the arena of social engagement that exists beyond the individual and under the state, within which individuals form their political identities (Andrée 2007).
} 


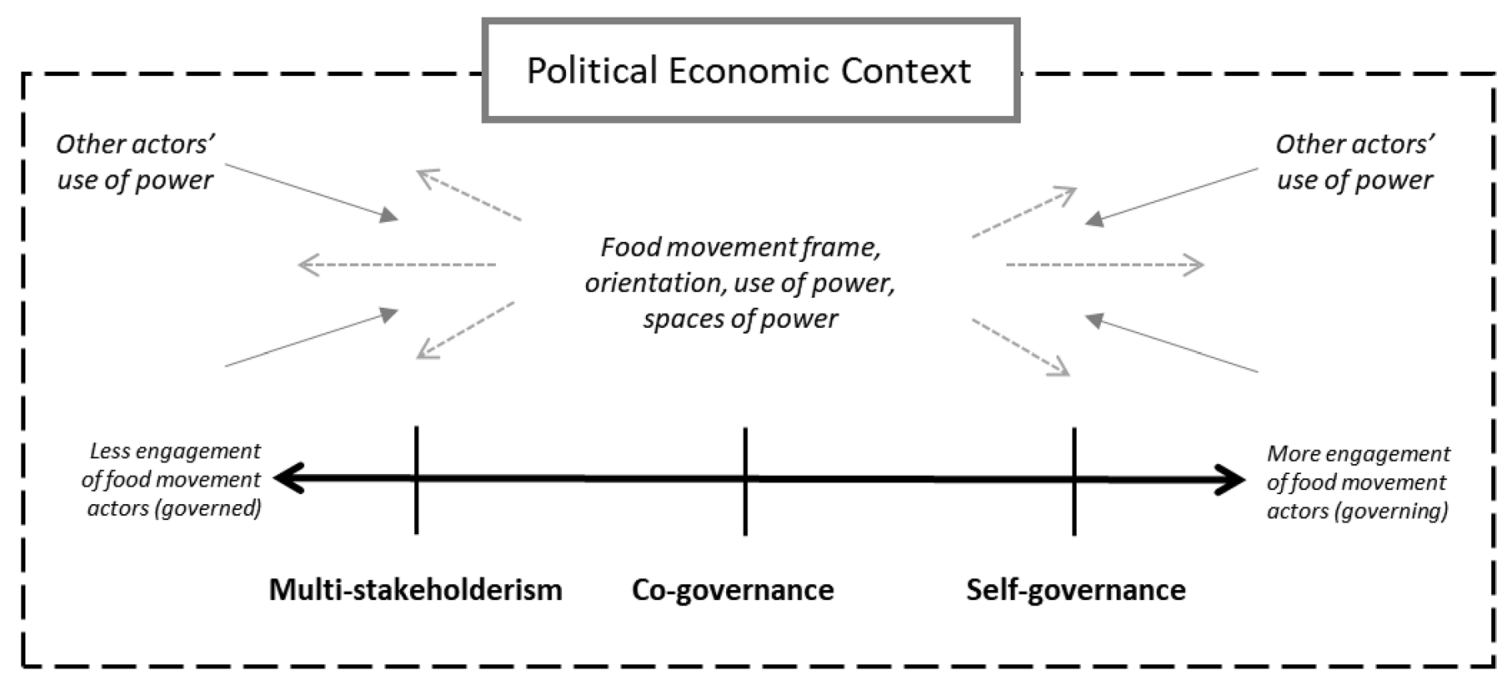

Fig. 1 Governance Engagement Continuum, 2.0

several FLEdGE members came together to workshop case studies on social movement governance engagement. Each of the cases involved academic researchers working in partnership with formal and informal organizations that adopt food movement causes, from food sovereignty and food system sustainability to organic transitions, all utilizing a food system approach. ${ }^{2}$ After an initial conversation, the authors of this paper developed a framework to compare these cases in a more structured way, and working with case authors, we published this diverse research in an edited volume (Andrée et al. 2019). Comparing cases led us to conclude that food movements seek to have a wider, systemic impact via governance arrangements with the state at a variety of scales and in a variety of forms (from multi-stakeholderism to cogovernance to self-governance). Movement actors use these diverse forms of governance engagement to reshape agendasetting processes, albeit with mixed success.

After publishing the book, we decided to revisit the cases for a closer look at a specific phenomenon. We observed that many involved social movement organizations actively creating new deliberative governance spaces, utilizing what we now call the "power to convene." This paper develops our post-hoc analysis, using the concept of relational fields. We find that the power to convene and create deliberative spaces is demonstrated in a variety of contexts, and it often results in outcomes that further movement aims, including repositioning food movement actors vis-à-vis others in the field.

\footnotetext{
${ }^{2}$ A food systems approach focuses on the interdependencies and relationships between the different parts of the food system and the various social and environmental forces acting on the system (van Berkum et al. 2018).
}

Below, we begin by reviewing the book's initial theoretical framework, followed by an introduction to the concept of relational fields and an outline of our methodological approach. In our findings section, we present brief descriptions of each of nine cases, focusing on those variables most relevant to this paper. The discussion presents our analysis of the "power to convene." Recognizing the limitations of our post-hoc approach, we conclude by raising additional questions to advance this research.

\section{The Governance Engagement Continuum}

In Andrée et al. (2019), we introduce the governance engagement continuum to theorize the ways that food movements mobilize resources to disrupt, influence, and/or engage in the execution of power through food system governance arrangements (Fig. 1). This continuum brings together the following elements that are important to understanding the emergence, efforts, and outcomes of food movements: orientation, framing, use of power, and political economic context (the top of the figure), along with a consideration of modes of governance (along the bottom). This section reviews the theoretical basis of the continuum, which we later relate to the proposed power to convene.

Figure 1 builds on the original governance engagement continuum. In particular, while this framework focuses primarily on movement engagement with the state, we recognize the often-formidable role of market actors, such as businesses and their associations, as one aspect of the political-economic context within which movement actors work. These forces are noted as "other actors' use of power" within the overarching "political-economic context." This depiction clarifies the continuum's purpose of honing in on movement 
participation while still considering the suite of actors that comprise the broader fields of political engagement in which social movements are operating.

\section{Movement orientation and issue framing}

How food movement actors frame issues and orient themselves to the dominant food system has important implications for why and how they engage in governance. Orientation refers to the strategic and ideological position that a movement actor takes in relation to the dominant food system (Stevenson et al. 2007; Holt Giménez and Shattuck 2011; McInnes and Mount 2017). We draw on Holt Giménez and Shattuck (2011) to describe three broad orientations: reformist, alternative, and transformative, although it should be noted that movement actors may embody multiple orientations simultaneously.

The reformist orientation attempts to work from within the dominant food system to achieve incremental changes. For example, reformists may work to strengthen food security by increasing access to food markets and healthier food options and improving existing social services and community food programming. As a form of governance engagement, such activity requires coordination across multiple scales and sectors and the involvement of diverse actors. The alternative orientation seeks to establish food system initiatives that exist in parallel to the dominant food system. Farmers' markets, organic supply chains, and fair-trade networks are typical examples. The governance engagement of this orientation often targets the regulation of food through a mix of formal (e.g., policies and laws) and informal (e.g., norms and relationships) mechanisms (Andrée et al. 2014; Sonnino 2007). Lastly, a radical orientation (such as food justice or food sovereignty) challenges the dominant system with more transformative goals aimed at addressing the root causes of inequality in the food system (Kloppenburg et al. 1996; Levkoe 2011; Jarosz 2000). In some cases, radical movements attempt to build new governance spaces entirely, such as Indigenous food sovereignty movements calling for self-determination and independence (Coté 2016).

\section{Use of power and spaces of power}

The continuum uses power as a central factor to explain food movement position in governance arrangements relative to their aspirations. We are informed by two key theoretical approaches, drawing first on Clapp and Fuch's (2009) analysis, which lays out instrumental, discursive, and structural power. Instrumental power involves wielding influence over others through direct action, fueled, in part, by the use of resources. Discursive power is about controlling discourse, developing or challenging narratives, and establishing new norms, which relates to the element of framing described above. Structural power is about defining the scope and institutional structures in which decisions are made. It sets agendas and legitimizes participation. To illustrate the settings within which power is used, we look to Gaventa's (2005) power cube, which distinguishes among different forms (visible, hidden, and invisible), levels (from local to global), and spaces (closed, invited, and claimed) of power. The power cube reminds us that governance spaces are not neutral and that power relations shape both who can enter certain spaces of participation and what is possible within them. Bringing these two approaches together to inform the continuum offers a fulsome analysis of power dynamics. For example, food movements may have an easier or harder time using power depending on the types of closed and invited spaces or forms of visible or hidden power they encounter.

\section{Political economic context}

Within the continuum, the political economic context refers to the confluence of economic, institutional, and discursive forces that define the field of political engagement at a particular historical moment (Andrée 2007; Gill and Law 1989; Gramsci 1971). This context includes the history of political and economic structures, various elites and publics, and value orientations in society. Some contexts may support the ways that food movements seek participation in governance, while other contexts, such as those captured by private interests, may not align with movement goals. This can sometimes lead to movement actors creating or convening new governance spaces (Claeys and Duncan 2019). We develop this idea of the power to convene further in this paper, which necessarily includes the institutional context of the state. Building on Johnston and Andrée (2019), we see value in distinguishing between institutional contexts as being "light" or "dense," referring to the density of the legal and regulatory webs laying over a particular issue area at a particular scale (e.g., the food system at the local level has a different institutional context than public housing at the local level).

\section{Modes of governance}

Together, these elements of orientation and framing, use of power, and political economic context help explain the position a food movement occupies on the continuum in terms of modes of governance (shown on the bottom of Fig. 1). ${ }^{3}$ The three modes of governance stem from interactive governance

\footnotetext{
${ }^{3}$ It is important to note that a movement actor is likely to occupy different positions on multiple governance engagement continua, depending on the decisions that are being made and the constellation of actors and other contextual forces involved in each situation.
} 
theory (Kooiman et al. 2008). On the far left of the continuum, multi-stakeholderism has food movement actors as one voice among many seeking to exercise influence in a pluralistic public sphere, with one powerful actor (typically government) formally holding the reins of decisionmaking. Here, food movement actors may exert influence but remain "governed" by top-down processes in which the state and market actors, as enabled by the state, lead problem- and rule-setting. On the far right of the continuum is the opposite ideal type, with movement actors actively shaping their own food systems through self-governance. In this case, social movements exert bottom-up control, framing issues and designing institutions that meet their needs. It is notable, however, that self-governance still takes place under the jurisdiction of one or more states and in coordination with market systems (Carlisle and Gruby 2019; Ostrom 2010). Co-governance sits between these two poles as an arrangement that involves sharing governance roles with other actors, including the state. In the ideal sense, multiple actors work together to meet shared governance goals. Co-governance focuses on consensus as opposed to simply managing competing stakes, reminding us that power "with" (versus power over) can be a shared force (Melé and Rosanas 2003).

\section{Conceptual and methodological approach}

In this paper, we build on our governance engagement continuum by taking a relational fields approach to tie the elements of the continuum together while analyzing emergent social movement dynamics and relationships in the case studies. At the core of our relational fields approach is a focus on social interactions and embeddedness in the field (Alimi et al. 2015; Moss and Snow 2016; Diani 2013). First, adopting a relational fields approach highlights the way actors construct their identities relative to one another (Fligstein and McAdam 2011). For example, a food movement's strategic orientation emerges from relations; strategy and orientation are not autonomous forces (Andrée et al. 2014). Second, choices made about creating, obtaining, and exercising power are not divorced from relationships (Alimi et al. 2015). A movement's use of power to change its position on the continuum may involve adopting a new frame to strengthen the relations of the actors in a field. It could equally involve creating new governance structures for working with other actors in the field, or aggregating resources with others to gain instrumental influence. Third, a relational fields approach adds depth to any understanding of the impact of a food movement actor's work. In a binary conceptualization (i.e., movements and governments as unitary actors, respectively), the success of movements is judged by policy change. From a relational perspective, success may involve altering relations and improving one's position vis-a-vis the state and other actors, with the latter outcomes resting on the skills of these actors in seeking advantages using a variety of tactics (Fligstein and McAdam 2011; Goldstone 2004).

While there is no single way to study field relations, it is common to emphasize emergent processes (Alimi et al. 2015; Fligstein and McAdam 2011). We adopt this approach in revisiting the nine FLEdGE network cases presented in Andree et al. (2019) for the purpose of explaining the emergent phenomenon. We consider these to be instrumental cases, or cases that offer support to refining a theory (Stake 1995). The particulars of each individual case are of less interest here than the insights that emerge from putting the cases into conversation with each other.

For each case, we documented critical case elements to gain an understanding of how food movement actors engaged in and changed governance processes, including the central movement actor(s) and case context as well as the positioning of movement actors within the field; the governance arrangement sought; the use and spaces of power; and outcomes, including material outcomes and shifts in position of movement actors. Beginning with the original text of the published cases, we then revisited each case with the case authors to fill in missing elements. As an author team, we worked together to discern key patterns and themes. All findings were developed via consensus. In addition, findings were shared with the case authors to confirm results.

\section{Cases}

This section presents the cases following the elements detailed in the previous section. We present a summary in Table 1.

\section{Dunedin, NZ-Local food system networks}

Dunedin is a New Zealand city of about 100,000 people, surrounded by agricultural production. In a neoliberal state focused on exports, local food policy was virtually nonexistent. This case from MacKay and Connelly (2019) covers the efforts of a grassroots group of local food advocates called Our Food Network Dunedin (OFN), which seeks to build a local food system that contributes to community resilience and prosperity. When their work began in 2013, OFN had no formal relationships with local government.

The framing (discursive power) used by OFN attracted many members interested in discussing a range of food system problems. OFN stimulated a deliberative conversation across a broad range of food system actors on an array of concerns, from local economies, food access, and environmental issues to health and wellbeing. After successfully 


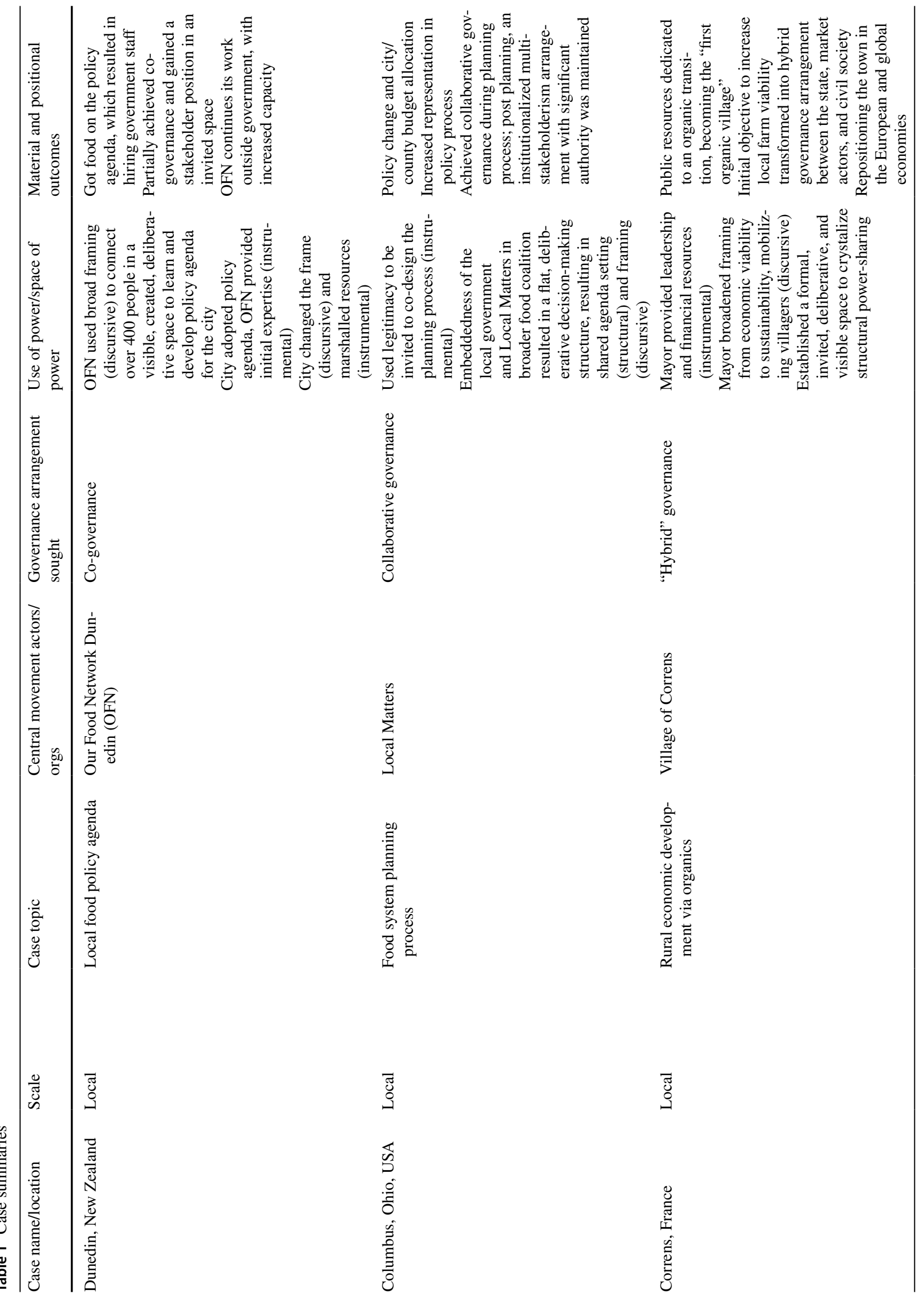




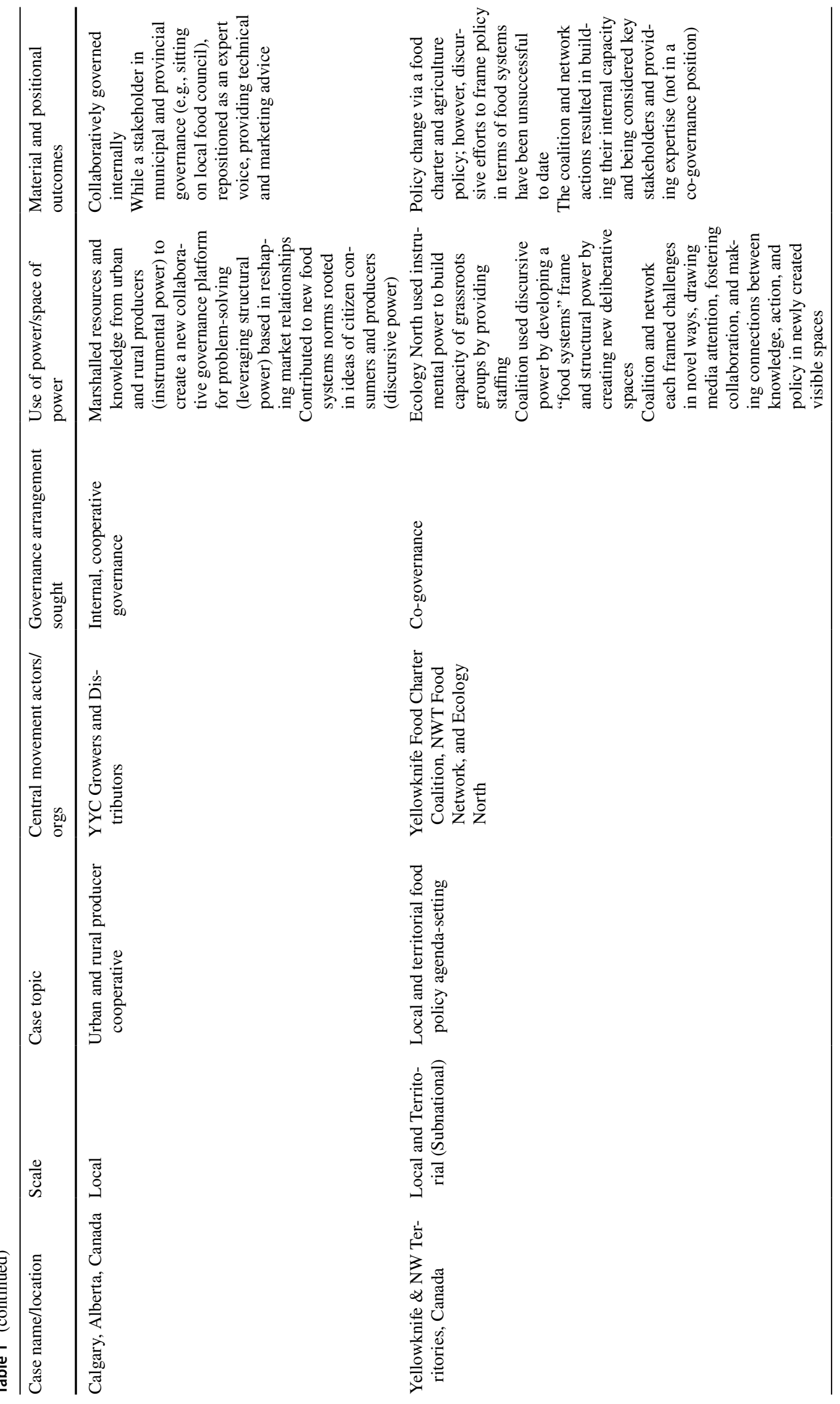




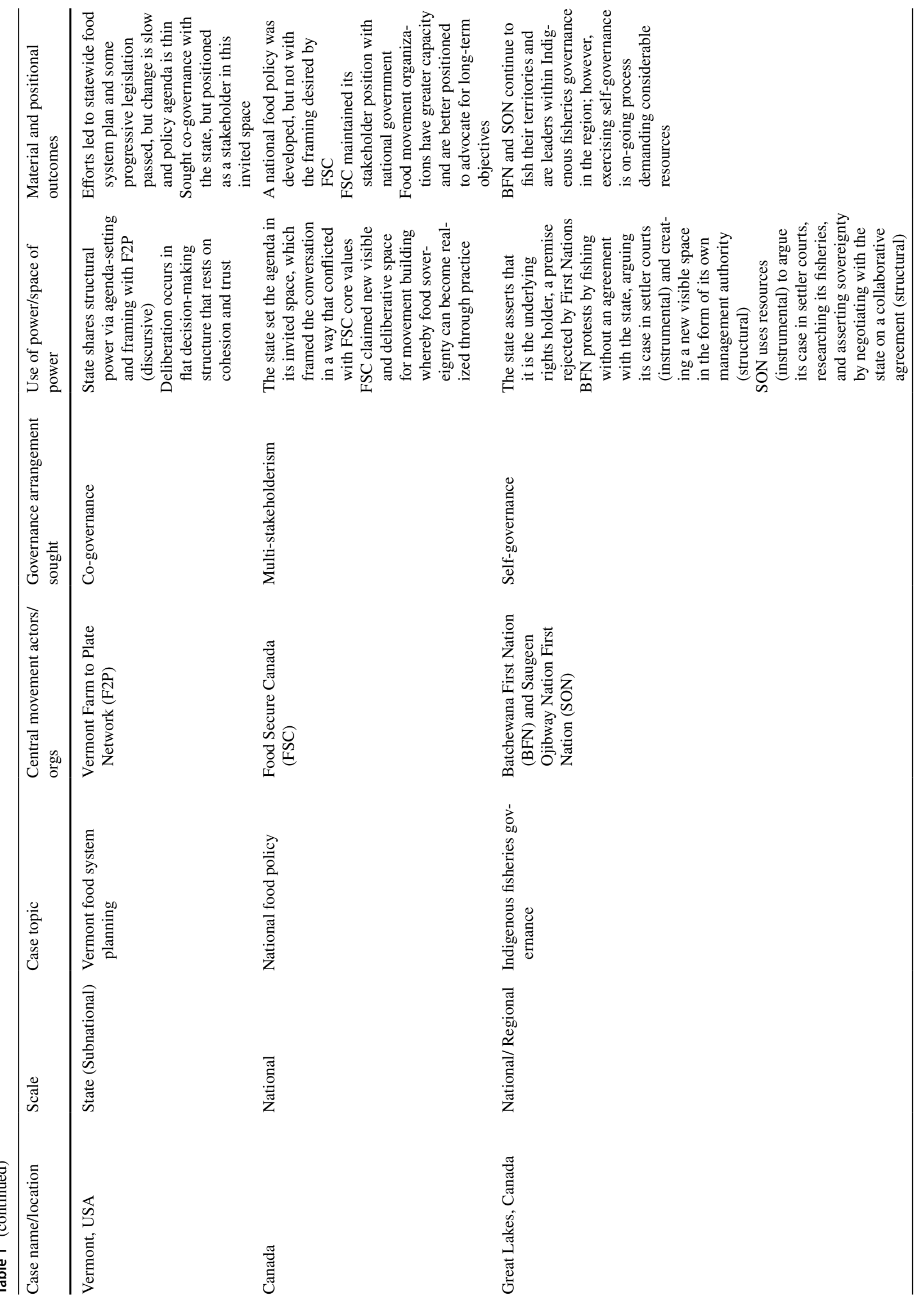


building a 400-member network, OFN set a broad agenda for the city. Taking up that agenda (creating a new invited space), the City of Dunedin invited OFN representatives to join a new advisory group to the city, alongside nutritionists, local food producers, and industry representatives. Despite OFN's efforts, however, city government shifted the framing of food system change from community food security and equity to economic development. OFN continues to work both inside and outside these structures. As such, OFN only partially achieved its co-governance objective.

Overall, OFN put food on the Dunedin policy agenda. It helped establish a local government position focused on food policy and provided significant capacity to support that position. While building city capacity, OFN simultaneously built its own capacity, formally becoming an incorporated entity that receives grants and conducts programs. Tensions remain, however, as OFN continues to push the city to adopt a more comprehensive food system change agenda.

\section{Columbus, Ohio, USA-Food system planning process}

This case from Clark (2019) is set in a Midwestern metropolitan area of over 1 million people that, like many cities in the United States, suffers from high rates of chronic disease and poverty, coupled with struggling farmers. These food system problems are a focus for Local Matters, a social movement organization whose mission is "to create healthy communities through food education, access and advocacy." Since its inception in 2009, Local Matters began meeting with city officials. At the same time, it helped launch a grassroots, volunteer food policy council that included invited city and county employees.

Increasingly, Local Matters and the food policy council requested city and county government support and policy change. Both governments recognized the need for a food action plan to guide decisions, and the food policy council and Local Matters pressured the governments to work together on this plan, bringing legitimacy to the process through their history of community organizing, relationship building, and programming. Local Matters was thus invited to a visible, deliberative space. Each participating organization had different values and approaches, but they shared a commitment to local food system change.

Neither city or county had jurisdiction over the other, and the social movement organization held a visible position in the community. These factors, together with the fact that all were embedded in a network with a shared vision, resulted in a horizontal governance arrangement. Working together required considerable time to negotiate disagreements, of which there were many. Despite Local Matters being contracted by the city (instrumental power), reciprocity and perceived fairness between organizations made this flat 
structure work. Local Matters was able to co-set the agenda (structural power) and frame the issues (discursive power), using deliberation to negotiate differences.

Collectively, these actors developed a joint plan that was adopted by the city and county, resulting in policy and budget changes. Through Local Matters' dedication to an inclusive, deliberative engagement approach, 150 community members from the city's most impoverished neighborhoods participated in the plan's first phase. Further, the city and county jointly established a Local Food Team, which facilitates an appointed twelve-person board (six from the county and six from the city) charged with plan implementation. Local Matters and the food policy council both participate on the board. The council (still made up of grassroots volunteers) now benefits from a Local Food Team staff person's time in exchange for committing to conduct community engagement. This agreement was brokered during the planning process. To this day, the governance structure has the legitimacy of government, community groups, and businesses; the authority of local government; accountability to both government and the community; resiliency to leadership change; and the strength of a growing social infrastructure.

\section{Correns, France-Rural economic development via organics}

Correns is a rural community with strong social ties built on trust and reciprocity and overlapping engagement among civil society, private enterprises, and the public sector. Over 90 percent of villagers are paysans who are involved in small-scale agriculture in some respect. As agriculture modernized, the changes negatively impacting local growers, causing a loss of village identity. This case from WeiYing Clément (2019) covers the efforts of villagers to counter these trends. Led by the mayor (a winemaker himself), Correns became a movement, creating France's first "organic village" via community economic development.

This movement started with the mayor attempting to improve winemaker livelihoods. As a former head of an agrochemical firm who was disenchanted with agribusiness, he saw promise in bringing more market control to the village industry. He met with winemakers in informal locations such as the town café. These conversations led to the local wine cooperative adopting value-added market schemes (e.g., organic and Appellation d'Origine Controlée (AOC) labelling) as well as local government investments.

With these change in production practices, the mayor expanded the framing beyond paysan livelihoods to one of village sustainability. This shift led to the creation of a local chapter of UN Agenda $21,{ }^{4}$ which institutionalized a deliberative space to discuss and launch sustainability initiatives. The resultant governance structure purposefully includes equitable participation with respect to gender, age, paysans, business owners, and unemployed residents, in addition to elected officials.

While the mayor's initial goals were focused on increasing the local wine cooperative's viability, collective efforts resulted in what Wei-Ying Clément calls a "hybrid" governance arrangement between the state, market actors, civil society, and citizens meant to reposition the town within both the European and global economies. This case differs from the others in that local government catalyzed a village to become a social movement. Together, community actors leveraged all three forms of power to create local alternatives, while still engaging in global markets on their own terms. Village government provided leadership and financial resources (instrumental power), organic agriculture was used as a mobilizing frame for sustainable community development (discursive power), and a new citizen-based governance structure was developed to shift the balance of power between the municipality and citizens (thereby leveraging structural power for citizens' initiatives), creating a formal, invited, visible, and deliberative space to complement informal café conversations.

\section{Calgary, Alberta, Canada-YYC Growers and Distributors producer cooperative}

Responding to a growing demand for local food, YYC Growers and Distributors (YYC) was established in 2014. It consists of twenty urban and rural growers in and around the city of Calgary that collectively sell their products through a community supported agriculture program and at farmers' markets. YYC is committed to environmental and social justice, educating consumers, and influencing policy changes that support local food in a province that remains dominated by large-scale, export-oriented production. YYC engages with civil society groups to facilitate resilient local food systems and has found some supportive allies within the municipal and provincial governments.

This case from Beckie and Bacon (2019) focuses on the internal, self-governance structure of YYC as a producer cooperative and how it impacts collaboration with civil society and government. YYC marshals producer resources (instrumental power) and knowledge to create a new governance space based on reshaping market relationships and

\footnotetext{
$\overline{4}$ Agenda 21 is an action plan established in 1992 at Earth Summit held in Rio de Janeiro, Brazil through the United Nations towards the goal of sustainable development (see https://sustainabledevelopme nt.un.org/outcomedocuments/agenda21).
} 
empowering consumers through direct relationships (thereby leveraging structural power); at the same time, it has contributed to new food systems norms based around the ideas of citizen consumers and producers (discursive power). It has also created a platform for urban-rural collaboration and problem-solving.

YYC's democratic member control, collaborative decision-making, and knowledge sharing contributed to its success by enabling the cooperative to attract consumers supportive of its values and work with other organizations to strengthen local food systems. Through its success, YYC has caught the attention of the municipal and provincial governments. For example, the City of Calgary sought out YYC's technical and marketing expertise when developing of a new commercial urban agriculture pilot project. The provincial government also created a food council to provide guidance on growing local food systems, and it selected YYC as the only producer representative.

\section{Yellowknife \& Northwest Territories, Canada-Local food policy agenda-setting}

The Northwest Territories' (NWT) food system includes hunting, fishing and gathering, and limited agriculture. The region relies heavily on imported foods. It has a long history of state regulation of traditional fishing and hunting practices of Indigenous peoples, including placing Indigenous children in residential schools and imposing top-down conservation rules that ignored traditional knowledge and governance systems. Food insecurity and nutrition-related health issues are more prevalent in NWT than elsewhere in Canada, and arsenic pollution from the mining of gold ore near the city of Yellowknife has impacted that city's traditional food activities.

Johnston and Andrée (2019) detail two related cases that involve Ecology North (an environmental social movement organization). Ecology North already had working relationships with city and territorial governments, doing funded projects for them and informing policy at both levels. It sought to build the capacity of the NWT Food Network (initially spearheaded by Ecology North along with farmers) and the Yellowknife Food Charter Coalition (a local crosssectoral coalition spearheaded by community activists) to engage in governance arrangements. The Yellowknife Food Charter Coalition sought a city-wide food strategy and, ideally, a co-governance role in realizing it, while the NWT Food Network aimed to define a territorial food system strategy and inform the implementation and refinement of a recently released territorial agricultural strategy.

In both cases, Ecology North used instrumental power, in the form of staffing support, to nurture the coalition and network. Coalition and network partners then developed new deliberative spaces (structural power) by bringing together multiple voices (including city council members in the case of the network) within their organizations. These organizations framed challenges in novel ways (discursive power) by employing a systems approach that connected food insecurity to hunting, fishing, and agriculture; drew media attention; fostered broader collaboration; and made connections between knowledge, action, and policy.

With greater capacity, both the coalition and the network sought to inform and shape new governance mechanisms within existing institutions at the city and territorial levels. The coalition developed a food charter that it used it to pressure the city government to develop an integrated food strategy. The City of Yellowknife responded with a food and urban agriculture strategy, thereby institutionalizing food in city policy. However, the comprehensive food systems approach and collaborative governance model that the Coalition sought has not yet materialized.

The network was successful in informing territorial agricultural policy and establishing itself as an expert producer voice, resulting in the network changing its name and refining its orientation. The new NWT Agri-Food Association brings a collective voice to territorial agricultural policy discussions. This was not the food system framing Ecology North and some of its partners initially promoted, but the new Association exerts influence as a key invited participant in territorial policy processes.

\section{Vermont, USA-Vermont Farm to Plate Network}

Vermont is a rural, demographically homogenous, and progressive state with a long history of supporting local and regional foods. Dairy is the primary component of the agricultural industry, and the two largest buyers and processors are member-owned cooperatives, unlike other states that are dominated by private- or corporate-owned businesses. The state embarked on a planning process by inviting over 1,200 farmers, food producers, technical assistance providers, and industry leaders from across the state. Participants included Vermont Sustainable Jobs Fund, a civil society organization, and Northeast Organic Farming Association and Rural Vermont, two social movement organizations. One outcome of the planning process was the development of the Vermont Farm to Plate Network (F2P). Anderson's (2019) case details the F2P, which is a network of government and civil society organizations supported by government resources (mainly through state-funded staff).

Leadership of the network rotates and is voted in by network members. The structure and decision-making processes in F2P are flat, and while there is no coercion, progress is slow. That means that structural and discursive power is shared within the network. F2P emphasizes information sharing, cooperation, and open dialogue. Annual conversations are co-constructed among civil society, farmers, and 
the government. F2P also collaborates with other organizations, using their deliberative processes to build capacity to address food system needs. For instance, F2P has consolidated efforts by anti-hunger, health, and economic development organizations to inform and boost COVID-19 relief.

One way F2P manages conflict is to advocate for policy change only when it is for legislation that is clearly directed at agreed-upon goals. Thus, while F2P has been successful at passing progressive legislation, it is not always able to accomplish all the changes it desires. For instance, Vermont had a Republican governor who did not always support small-scale farmers or additional benefits for low-income people. Despite power differentials, with the state having more instrumental power in the form of authority and funding, cohesion and trust enable deliberation. Still, while F2P seeks a co-governance arrangement with the state, it remains positioned as just one of many a stakeholders in this invited space.

\section{Canada-National food policy}

This case from Levkoe and Wilson (2019) traces the work of Food Secure Canada (FSC), a pan-Canadian food movement alliance made up of individuals, civil society organizations, and grassroots groups. Its mandate is to advance food security and food sovereignty through three interlocking goals: zero hunger, healthy and safe food, and sustainable food systems. Social movement actors and organizations have a long history of coming together to deliberate on how to improve Canada's food system, though over time actions have become less grassroots and more institutionalized in term of governance. In 2015, the newly elected Liberal Party announced its commitment to develop a national food policy, beginning with the development of a process for consultation.

FSC saw the government process as an opportunity to marshal resources and impact the framing of the national food policy. However, the government used its power in determining the agenda (structural), putting pressure on social movement actors to fit within the government's preexisting framework in order to be considered legitimate and influence the policy discussion (given the state's instrumental power). This resulted in tensions within FSC, with some actors pulled towards maintaining more radical positions outside the government's purview and others attempting to work within the predetermined process.

Both in response to and in parallel with the government-led policy consultation process, FSC led a series of engagement activities involving more than seventy member organizations and allies in an attempt to prefigure a food systems approach to policy while modeling participatory food governance through collaboration and deliberation. In contrast to the government's consultation process, FSC's initiatives were not solely focused on deriving policy outcomes. Instead, the activities and outputs strengthened the food movement through network building, enhanced capacity, and bringing forward grassroots perspectives.

While the state ultimately pushed multi-stakeholderism, FCS used the government's invited space, as well as its own claimed space, for movement building. FSC's approach to prefiguration illustrates how food sovereignty can be realized in practice through policy processes, not just policy outcomes. Prefiguration was a tool for managing the tension and complexity of working both "inside" and "outside" the state, acting, to a degree, as an insulating force against pressures of co-optation by enabling social movement organizations to engage with the state and policy-building on their own terms.

\section{Great Lakes, Canada_Indigenous fisheries}

Lowitt et al. (2019) consider two case studies of Indigenous fisheries governance in the Great Lakes region of Ontario, Canada: Batchewana First Nation (BFN) and Saugeen Ojibway Nation (SON). Access to fishing as part of their traditional food systems is a key element of food sovereignty for both communities. The arrival of Europeans in the 1700s forcibly disrupted Indigenous fishing activities, and ongoing settler colonialism threatens access to traditional territories and food systems. The Canadian state maintains that it holds the underlying title to land in Canada, including control of fisheries. First Nations challenge this premise.

While state-led fisheries management is based on efficiency and profit, governance of fisheries for both BFN and SON is deeply interconnected with ecosystems and their cultures. The two First Nations assert existing self-governing processes within a settler state regime. In asserting its sovereignty, SON has chosen to enter into a co-governance arrangement, essentially co-creating a new visible space with the provincial and federal governments concerning the management of commercial fisheries within its traditional waters. BFN has not sought any co-governance arrangement, instead claiming space for decision-making separate from the state.

BFN demonstrates instrumental power through protest, actively fishing without an agreement with the state and arguing their case in settler courts. They have demonstrated structural power by creating their own traditional fisheries management authority, deliberately rejecting the state's legitimacy and furthering their claim to self-determination. SON has taken a different approach, using its resources (instrumental power) to argue its case in settler courts, conduct research about its fisheries, and assert sovereignty by negotiating with the state on the implementation of a collaborative agreement (structural power) that recognizes the principles upon which it bases its fisheries. 
BFN and SON operate among the largest Indigenous fisheries on the Canadian side of the Great Lakes, and they make significant contributions to their livelihoods, cultures, and food systems. They have each established forms of engagement (and disengagement) with the state that align with their needs and values. However, asserting self-governance is an ongoing process that takes a physical and emotional toll as the state continues to disregard the inherent and preexisting rights that these communities assert.

\section{United Nations-Committee on World Food Security}

In 1974, the United Nations created the Committee on World Food Security (CFS) in response to a global food crisis. After 2009 food price spikes left 75 million more people with food shortages and led to instability in several countries, the UN revamped the CFS structure to better predict major food access problems. The UN determined that civil society should have a greater role, given its knowledge and experience. La Via Campesina, a prominent international social movement organization, was invited to help set the terms of the reform, thereby bringing civil society to the CFS table (although only member states vote). This case from Anderson (2019) addresses the Civil Society and Indigenous Peoples' Mechanism (CSM) that was developed for the purposes of engaging with the CFS. No other intergovernmental forum invites civil society to participate in setting the agenda (sharing structural power) and participate in deliberation along with government delegates and observers. However, CSM participants in the CFS have no voting power. The CSM is just one entity among many others, and the CFS is itself a multi-stakeholder governance arrangement. Given these limitations, some social movements challenge the idea of bringing more vulnerable people to the table without real power.

CSM members meet for capacity building and invite CFS members to participate. Further, the CFS, recognizing power differentials between member states and the CSM, puts financial (instrumental) resources towards building CSM's capacity to engage more effectively in the process. This funding is used to support social movement members of the CSM, as opposed to nongovernment organization members. CSM also preferentially selects social movement members to speak in plenary and in committees, given their direct experience and that many want to speak for themselves.

CFS leadership appreciates the deep political analysis and institutional history that CSM constituents bring to conversations. However, chairs and the Secretariat can be hostile to CSM representatives for these very reasons. Within this environment, the CSM has had policy successes (using discursive power), including reaching an agreement with the CFS that no policies or recommendations could be made that interfere in any way with the right to food and nutrition.
However, CSM members must remain vigilant, as some member states remain resistant to them.

\section{Discussion}

In the findings presented above, we used the concept of relational fields to conduct a post-hoc analysis of nine cases, examining how social movement organizations and other actors actively create "new" deliberative governance spaces through the "power to convene." The power to convene is not a new form of power. Rather, the concept enables food movement scholars and practitioners to see governance opportunities and challenges in a new way. In the context of the theory informing our governance engagement continuum, convening occurs at the intersection of discursive and structural power, where it can be grounded in the power to reframe narratives through deliberation while enabling the construction of a new governance space. As with any change, (instrumental) resources are required for convening. In some cases, this requirement allows movement actors to leverage instrumental power by assembling resources and repositioning actors. The power to convene can be related to Gaventa's (2005) claimed or created spaces, in that likeminded people organically create spaces for themselves. However, unlike Gaventa's conceptualization, convened spaces are not necessarily about resistance, and they are not only created by and for marginalized, non-state, or nonmarket actors. The power to convene is necessarily visible, relying on transparency.

The cases reveal at least five important aspects of the power to convene and create deliberative spaces. First, convening occurs in "light" or "dense" institutional contexts (e.g., regulatory, legal, etc.). In light contexts, social movement organizations and actors can utilize their deeply rooted, place-based networks to their advantage. In dense contexts, convening can be used to create new spaces to assemble resources. A relational fields approach suggests that when the institutional context comes together with the use and spaces of power and modes of governance, the power to convene will look different between cases. For example, we see the power to convene across several cases in light contexts (e.g., Columbus, Dunedin, and NWT). Convening involves inviting government actors to a space, but the expression on the ground may look quite different. In dense contexts, convening can be about building the capacity of a movement to engage with government, but convening in the case of Canadian National Food Policy or CSM look very different, with the former paralleling a governance process and the latter being supported by and integrated into an ongoing governance process.

Second, the act of convening can increase the capacity of movement actors through, for example, co-learning 
and collective problem-solving and strategizing, as seen in the cases of Dunedin, YYC Growers, and Food Secure Canada. A long tradition of research demonstrates capacity building through deliberation (Nabatchi et al. 2012). Deliberative spaces with inclusive frames can be used for movement building, including creating connections between new groups of people and reinforcing community and social capital, which can later be mobilized to assemble and leverage resources, as seen in the case of Correns.

Capacity building also results from a third aspect of the power to convene, which is using this power to create deliberative spaces in an attempt to prefigure policymaking along more inclusive policy processes that the movements want to see. In this way, the power to convene can be seen as "constituting" a new forum by changing the rules of who belongs and how decisions are made (Ostrom 1989). Prefiguration means that the organization of movement actors to engage in governance processes can be seen by the movements as valuable in and of itself. In several of the cases, social movement organizations were motivated to increase inclusivity in processes for a more democratic approach or more internal capacity, or to more broadly enhance the governance capacity of a place via co-learning and network building (e.g., the National Food Policy in Canada, United Nations Committee on World Food Security, and food planning in Columbus). In the case of Food Secure Canada, the process of prefiguration built resilience in the movement by introducing democratic processes within its own work, protecting it from challenges and tensions between the movement and the state and building its own instrumental power and capacity.

The above focus on process and inclusive framing suggests a fourth aspect, the ability to engage with relational fields in a way that is particularly important in addressing problems in the food system, namely a process to integrate, coordinate, and build a systems-oriented vision. A meaningful difference exists between a policy issue that has an easily defined set of goals and outcomes and a systems issue, which does not have a single policy goal or outcome. The power to convene and deliberate facilitates the exploration and understanding of the connections between activities and outcomes in the food system. For example, the Canadian National Food Policy illustrates how Food Secure Canada was able to bring a systems approach by successfully pushing for the development of a national food advisory council despite the government's siloed approach. However, not all cases were successful. The efforts of social movement organizations in the NWT to reframe issues through a food systems lens were reduced to an agricultural focus to keep it manageable for governments. Civil society can build inclusive, deliberative communities and in so doing expand the agenda to work on issues that may not have been the movement actors' original intentions. However, this process can surface tensions between differing goals and create contested relations, which can have negative consequences if such tensions within movements are not held and then built on.

Finally, the power to convene and deliberate plays a role in both material and positional outcomes. For example, a food system plan was adopted, several local policies were passed to support sustainable food systems, and city and county government funds were dedicated for implementation in Columbus. Vermont now has a statewide food system plan to guide policy decision. In a few places, policies were passed but did not fully use the systems frame desired by social movement organizations (e.g., Canada's National Food Policy and NWT's food charter and agricultural policy). Success can also be defined as the repositioning of actors within the relational field in a way that benefits them, particularly because organizations' goals were not just about policy outcomes, but changes in governance processes that resulted in a seat at the table in nearly all our cases. Finally, the power to convene provides the potential that, if realized to its full extent, can shift relational fields to support selfgovernance goals. Specifically, in the case of Indigenous fisheries in the Great Lakes, convening and creating may be a way of shifting the relational field towards a new balance of power such that these communities once again become the primary power holders within their territories. Again, not all cases were successful. In Dunedin, OFN wanted a new position in co-governance, but ultimately its position remains largely the same. However, it was successful in the passage of a new policy and public financial resources allocations despite having no formal role in the decision-making structure. In short, our cases reaffirm that success is not just measured as policy outcomes, but as an advantageous repositioning of movement actors in fields that enables an ongoing governance role.

Given that our approach was a post-hoc analysis of cases, we call for further systematic empirical examination of the concept of the power to convene and deliberate, its expression in change-making, and how that expression varies given different types of food movement actors. Further research is also necessary on the specific mechanisms at play between convening and material and positional outcomes for social movement organizations to examine why convening resulted in desired outcomes in some cases (e.g., Columbus), while in other places it did not (e.g., Dunedin). Moreover, we have just scratched the surface regarding the application of relational fields and food movements. This suggests stepping back to chart the central field elements for a variety of food movements actors, such as the bounds of fields, actors and governance units, the social skills used, the broader environment (particularly the relationship between scales of governance), and other variables that may impact food movements' engagement in fields and emergent governance dynamics (Fligstein and McAdam 2011). 


\section{Conclusion}

In the context of serious challenges, food movements are seeking to make food systems more just and sustainable by addressing systemic issues by engaging directly with governance. As community-based researchers engaging in participatory research, we have integrated theory and practice by demonstrating how the power to convene contributes to strategic thinking about the current governance of food systems and ways to enact new governance possibilities that address food system complexities. Drawing on nine cases, we argue that food movement successes (albeit mixed across our cases) are related to the "power to convene," a process-oriented approach that increases movements' capacity to mobilize; leverage different types of power; and integrate, coordinate, and build a systemsoriented vision by connecting across silos. The power to convene and create deliberative spaces is demonstrated in a variety of contexts and often results in outcomes that further movement aims. Crucially, success is not only about policy outcomes, but about the repositioning of actors within the relational field in a way that benefits movement aims. Further, recognizing that agendas are multifaceted (e.g., sustainable livelihoods for farmers, reduced environmental pollution, greater equity, Indigenous selfdetermination), these actors are usually not looking to achieve one-time policy "asks." Instead, they want to play a meaningful role as part of ongoing governance structures. By convening, actors may better position themselves to influence long-term systems change, as relational fields are dynamic over space, scale, and time.

Acknowledgements Foremost, we thank the authors of the cases analyzed in this research, who include Molly D. Anderson, Elizabeth Bacon, Mary Beckie, Chantal Wei-Ying Clément, Sean Connelly, Carla Johnston, Ryan Lauzon, Philippa MacKay, Kathleen Ryan, Chief Dean Sayers, and Amanda Wilson. We thank Alison Blay-Palmer for her continued support of our research. We thank Sarah Berger Richardson, Mike McGinnis, Annie Shattuck, and members of the Ostrom Workshop for their valuable feedback on an earlier draft. Finally, we thank the three anonymous reviewers who provided excellent feedback on the initial submission.

\section{References}

Aligica, Paul D., and Vlad Tarko. 2012. Polycentricity: From Polanyi to Ostrom, and beyond. Governance 25 (2): 237-262.

Alimi, Eitan Y., Lorenzo Bosi, and Chares Demetriou. 2015. The dynamics of radicalization: A relational and comparative perspective. Oxford: Oxford University Press.

Altieri, Miguel A. 2018. Agroecology: The science of sustainable agriculture. London: CRC Press.

Anderson, Molly D. 2019. Comparing the effectiveness of structures for addressing hunger and food insecurity. In Civil society and social movements in food system governance, ed. P. Andree, J.K. Clark, C.Z. Levkoe, and K. Lowitt, 124-144. Oxforshire: Routledge.

Andrée, Peter. 2007. Genetically modified diplomacy: the global politics of agricultural biotechnology and the environment. Genetically modified diplomacy: The global politics of agricultural biotechnology and the environment.

Andrée, Peter, Jeffrey Ayres, Michael Bosia, and Marie-Josée Mássicotte. 2014. Globalization and food sovereignty: Global and local change in the new politics of food. Toronto: University of Toronto Press.

Andrée, Peter, Jill K. Clark, Charles Z. Levkoe, and Kristen Lowitt. 2019. Civil society and social movements in food system governance. Oxforshire: Routledge.

Ansell, Christopher. 2003. Community embeddedness and collaborative governance in the San Francisco Bay Area. In Social movements and networks: Relational approaches to collective action, ed. M. Diani and D. McAdam, 123-144. Oxford: Oxford University Press.

Beckie, Mary, and Elizabeth Bacon. 2019. 4 Catalyzing change in local food system governance in Calgary, Alberta. In Civil society and social movements in food system governance, ed. P. Andree, J.K. Clark, C.Z. Levkoe, and K. Lowitt, 81-100. Oxforshire: Routledge.

Carlisle, Keith, and Rebecca L. Gruby. 2019. Polycentric systems of governance: A theoretical model for the commons. Policy Studies Journal 47 (4): 927-952.

Claeys, Priscilla, and Jessica Duncan. 2019. Do we need to categorize it? Reflections on constituencies and quotas as tools for negotiating difference in the global food sovereignty convergence space. The Journal of Peasant Studies 46 (7): 1477-1498.

Clapp, Jennifer. 2016. Food. Cambridge UK: Polity Press.

Clapp, Jennifer, and Doris A. Fuchs. 2009. Corporate power in global agrifood governance. Cambridge, MA: MIT Press.

Clark, Jill K. 2019. Collaborative governance: The case of local food action planning. In Civil society and social movements in food system governance, ed. P. Andree, J.K. Clark, C.Z. Levkoe, and K. Lowitt, 164-182. Oxforshire: Routledge.

Constance, Douglas H., Marie-Christine Renard, and Marta G. Rivera-Ferre. 2014. Alternative agrifood movements: Patterns of convergence and divergence. Bingley: Emerald Group Publishing Ltd.

Coté, Charlotte. 2016. "Indigenizing” food sovereignty. Revitalizing Indigenous food practices and ecological knowledges in Canada and the United States. Humanities 5 (3): 57.

Crossley, N., and M. Diani. 2018. Networks and fields. In The Wiley Blackwell companion to social movements, ed. D.A. Snow, S.A. Soule, H. Kriesi, and H.J. McCammon. Hoboken: Wiley.

Dachner, N., and V. Tarasuk. 2016. Origins and consequences of and responses to food insecurity in Canada. In Critical perspectives in food studies, 2nd ed, ed. M. Koc, J. Sumner, and A. Winson, 221-236. Toronto: Oxford University Press.

Desmarais, Annette Aurelie, Priscilla Claeys, and Amy Trauger. 2017. Public policies for food sovereignty: Social movements and the state. London: Routledge.

Diani, Mario. 2013. Organizational fields and social movement dynamics. In The future of social movement research: Dynamics, mechanisms, and processes, ed. J. Van Stekelenburg, C. Roggeband, and B. Klandermans, 145-168. Minneapolis: University of Minnesota Press.

Fligstein, Neil, and Doug McAdam. 2011. Toward a general theory of strategic action fields. Sociological Theory 29 (1): 1-26.

Friedland, William H. 2010. New ways of working and organization: Alternative agrifood movements and agrifood researchers. Rural Sociology 75: 601-627. https://doi.org/10.111 1/j.1549-0831.2010.00031.x. 
Gaventa, John. 2005. Reflections on the uses of the "power cube' approach for analyzing the spaces, places and dynamics of civil society participation and engagement. Participatory Methods. https://www.participatorymethods.org/sites/participatoryme thods.org/files/reflections_on_uses_powercube.pdf. Accessed 13 August 2020.

Gill, Stephen R., and David Law. 1989. Global hegemony and the structural power of capital. International Studies Quarterly 33 (4): 475-499.

Goldstone, Jack A. 2004. More social movements or fewer? Beyond political opportunity structures to relational fields. Theory and Society 33 (3-4): 333-365.

Gramsci, Antonio. 1971. Selections from the prison notebooks (trans: Q. Hoare \& GN Smith). New York: International Publishers.

Gray, Margaret. 2013. Labor and the locavore: The making of a comprehensive food ethic. Berkeley: University of California Press.

Hendrickson, Mary K., and William D. Heffernon. 2002. Opening spaces through relocalization: Locating potential resistance in the weaknesses of the global food system. Sociologia Ruralis 42 (4): 347-369.

Holt Giménez, Eric, and Annie Shattuck. 2011. Food crises, food regimes and food movements: Rumblings of reform or tides of transformation? The Journal of Peasant Studies 38 (1): 109-144.

Jarosz, Lucy. 2000. Understanding agri-food networks as social relations. Agriculture and Human Values 17 (3): 279-283.

Jayaraman, Saru. 2013. Behind the kitchen door. Ithaca: Cornell University Press.

Johnston, Carla, and Peter Andrée. 2019. Pathways to co-governance?: The role of NGOs in food governance in the Northwest Territories, Canada. In Civil society and social movements in food system governance, ed. P. Andree, J.K. Clark, C.Z. Levkoe, and K. Lowitt, 43-62. Oxforshire: Routledge.

Kloppenburg, Jack, John Hendrickson, and G.W. Stevenson. 1996. Coming in to the foodshed. Agriculture and Human Values 13 (3): 33-42. https://doi.org/10.1007/BF01538225.

Kooiman, J. 2003. Governing as governance. Thousand Oaks: Sage.

Kooiman, Jan, Maarten Bavinck, Ratana Chuenpagdee, Robin Mahon, and Roger Pullin. 2008. Interactive governance and governability: An introduction. The Journal of Transdisciplinary Environmental Studies 7 (1): 1-11.

Laforge, Julia M.L., Colin R. Anderson, and Stéphane M. McLachlan. 2017. Governments, grassroots, and the struggle for local food systems: Containing, coopting, contesting and collaborating. Agriculture and Human Values 34 (3): 663-681.

Lang, Tim, David Barling, and Martin Caraher. 2009. Food policy: Integrating health, environment and society. Oxford: Oxford University Press.

Levkoe, Charles Z. 2011. Towards a transformative food politics. Local Environment 16 (7): 687-705. https://doi.org/10.1080/13549 839.2011.592182.

Levkoe, Charles Z. 2014. The food movement in Canada: A social movement network perspective. Journal of Peasant Studies 41 (3): 385-403.

Levkoe, Charles Z. 2015. Strategies for forging and sustaining social movement networks: A case study of provincial food networking organizations in Canada. Geoforum 58: 174-183.

Levkoe, Charles Z., and Amanda Wilson. 2019. Policy engagement as prefiguration: Experiments in food policy governance through the national food policy dialogue in Canada. In Civil society and social movements in food system governance, ed. P. Andree, J.K. Clark, C.Z. Levkoe, and K. Lowitt, 101-123. Oxforshire: Routledge.

Lowitt, Kristen, Charles Z. Levkoe, Ryan Lauzon, Kathleen Ryan, and Dean Sayers. 2019. Indigenous self-determination and food sovereignty through fisheries governance in the Great Lakes Region. In Civil society and social movements in food system governance, ed. P. Andree, J.K. Clark, C.Z. Levkoe, and K. Lowitt, 145-163. Oxforshire: Routledge.

MacKay, Philippa, and Sean Connelly. 2019. 3 Searching for fit? In Civil society and social movements in food system governance, ed. P. Andree, J.K. Clark, C.Z. Levkoe, and K. Lowitt, 63-80. Oxforshire: Routledge.

Martin, John Levi. 2003. What is field theory? American Journal of Sociology 109 (1): 1-49.

McInnes, Ashley, and Phil Mount. 2017. Actualizing sustainable food systems. In Critical perspectives in food studies, ed. A. Winson, J. Sumner, and M. Koc. Oxford: Oxford University Press.

Melé, Domènec, and Josep M. Rosanas. 2003. Power, freedom and authority in management: Mary Parker Follett's 'power-with'. Philosophy of Management 3 (2): 35-46.

Moss, Dana M., and David A. Snow. 2016. Theorizing social movements. In Handbook of contemporary sociological theory, ed. S. Abrutyn, 547-569. New York: Springer.

Nabatchi, Tina, John Gastil, Matt Leighninger, G. Michael. Weiksner. 2012. Democracy in motion: Evaluating the practice and impact of deliberative civic engagement. Oxford: Oxford University Press.

Nagendra, H., and E. Ostrom. 2012. Polycentric governance of multifunctional forested landscapes. International Journal of the Commons 6 (2): 104-133.

Ostrom, Elinor. 1989. Microconstitutional change in multiconstitutional political systems. Rationality and Society 1 (1): 11-50.

Ostrom, Elinor. 2010. Beyond markets and states: Polycentric governance of complex economic systems. American Economic Review 100 (3): 641-672.

Pauly, Daniel, Rainer Froese, and Maria Lourdes Palomares. 2000. Fishing down aquatic food webs: Industrial fishing over the past half-century has noticeably depleted the topmost links in aquatic food chains. American Scientist 88 (1): 46-51.

Power, Elaine M. 2008. Conceptualizing food security for Aboriginal people in Canada. Canadian Journal of Public Health 99 (2): 95-97.

Renting, Henk, Terry K. Marsden, and Jo Banks. 2003. Understanding alternative food networks: Exploring the role of short food supply chains in rural development. Environment and Planning A 35: 393-411.

Schiff, Rebecca, and Charles Z. Levkoe. 2014. From disparate action to collective mobilization: Collective action frames and the Canadian food movement. In Occupy the earth: Global environmental movements, ed. L. Leonard and S. Buryn Kedzior, 225-253. Emerald Group Publishing Limited: Bingley.

Sonnino, Roberta. 2007. Embeddedness in action: Saffron and the making of the local in southern Tuscany. Agriculture and Human Values 24 (1): 61-74.

Stake, Robert E. 1995. The art of case study research. Thouand Oaks: Sage.

Stevenson, G.W., Kathryn Ruhf, Sharon Lezberg, and Kate Clancy. 2007. Builder, weaver, and warrior work: Strategies for changing the food system. In Remaking the North American food system: Strategies for sustainability, ed. C.C. Hinrichs and T.A. Lyson. University of Nebraska Press: Lincoln.

van Berkum, Siemen, Just Dengerink, and Ruerd Ruben. 2018. The food systems approach: sustainable solutions for a sufficient supply of healthy food. Wageningen: Wageningen Economic Research. Food a\& Business Knowledge Platform. https://knowl edge4food.net/food-systems-approach-report/. Accessed 13 August 2020.

Clément., Wei-Ying. 2019. Hybrid governance as rural development: Market, state and civil society in Correns, France. In Civil society and social movements in food system governanc, ed. P. Andree, J.K. Clark, C.Z. Levkoe, and K. Lowitt, 183-200. Oxforshire: Routledge. 
Weis, Tony. 2013. The ecological hoofprint: The global burden of industrial livestock. London: Zed Books Ltd.

Williams, Justine M., and Eric Holt-Giménez. 2017. Land justice: Re-imagining land, food, and the commons. Oakland: Food First Books.

Wittman, H., A.A. Desmarais, and N. Wiebe. 2010. Food sovereignty: Reconnecting food, nature and community. Nova Scotia: Fernwood Publishers.

Publisher's Note Springer Nature remains neutral with regard to jurisdictional claims in published maps and institutional affiliations.

Jill K. Clark is associate professor in the John Glenn College of Public Affairs at Ohio State University. Her research interests include food policy and practice, centering on community and state governance of food systems, the policy process, and public participation.
Kristen Lowitt is assistant professor in the School of Environmental Studies, Queen's University. Her research looks at the interactions among food sovereignty, communities, and natural resource governance in rural and coastal regions.

Charles Z. Levkoe is the Canada Research Chair in Sustainable Food Systems in the Department of Health Sciences at Lakehead University. Charles' community engaged research uses a food systems lens to explore connections between social justice, ecological regeneration, regional economies and democratic engagement.

Peter Andrée is a Professor in the Department of Political Science at Carleton University. His research focuses onthe politics of food systems and the environment. He practices, and teaches, community-basedparticipatory research methods. 